\title{
INOVASI PEMBELAJARAN MELALUI BAI'AT DALAM MEMBENTUK KARAKTER KEDISIPLINAN PESERTA DIDIK
}

\author{
Agus Salim Mansyur'1, Nurti Budiyanti ${ }^{2}$, Asep Abdul Aziz ${ }^{3}$, Ari Prayoga ${ }^{4}$ \\ ${ }^{1,2,3}$ UIN Sunan Gunung Djati Bandung \\ ${ }^{4}$ Perkumpulan Sarjana Manajemen Pendidikan Islam (PERSMAPI) Indonesia \\ e-mail: assalam@uinsgd.ac.id
}

\begin{abstract}
Education aims to develop the character of learners. To achieve this goal, teaching methods are necessary in education. So far, there has been no effective method applied in developing the character of learners. this research provides an overview of the level of discipline resulted from the ba'iat, as an effort to form the character of learners. It intends to find about how discipline is taught, implemented, and the supporting and inhibiting factors of the implementation of discipline as well as the impact of discipline teaching and implementation through bai'at in forming the character of learners. This research is based on a theoretical study which states that the implementation of discipline through bai'at can significantly improve discipline, and discipline is a key indicator of success in character formation. The success of learners in the formation of their character is, in some degree, influenced by the firmness of implementing the bai'at method. In this research, the author employed qualitative-descriptive method to find out how discipline is taught, how it is implemented, and what factors supportand inhibit the implementation and the teaching of discipline. The author also used quantitative method to determine the impact of teaching and the implementation of discipline through bai'at on the character formation of learners. The research was conducted at Pesantren Persatuan Islam 1 Bandung, and the respondents were 137 tenth grade Mualimien learners. The results of this study illustrate that the discipline teaching was in good category, with an average score of 3.562. The disciplinary implementation was also in good category, with an average score of 3.562. Then, the supporting and inhibiting factors were in the good category with an average score of 3.562. Finally, the impact of teaching and implementation of discipline through bai' at in the character formation of learners was in very good category, with an average score of 4.242. Thus, based on the results of the calculation, it is found that the teaching of discipline through bai'at has positive impact on the formation of the character of tenth grade Mualimien students of Pesantren Persatuan Islam 1 Bandung.
\end{abstract}

Keywords: Bai'at; charact; discipline. 


\begin{abstract}
ABSTRAK
Pendidikan bertujuan untuk mengembangkan karakter peserta didik. Untuk mencapai tujuan tersebut, perlu adanya metode yang digunakan dalam dunia pendidikan. Sejauh ini, pendidikan belum mampu menerapkan metode yang efektif dalam mengembangkan karakter peserta didik. Penelitian ini memberikan gambaran mengenai tingkat kedisiplinan yang dihasilkan melalui bai'at, sebagai upaya pembentukan karakter peserta didik. Adapun tujuan dari penelitian ini ialah untuk mengetahui cara disiplin diajarkan, cara disiplin dilaksanakan, faktor pendukung dan penghambat penerapan disiplin serta dampak pengajaran dan pelaksanaan disiplin melalui bai'at dalam pembentukan karakter peserta didik. Penelitian ini bertolak dari kajian teoritis yang menyatakan bahwa penerapan disiplin melalui bai'at memiliki peningkatan disiplin yang cukup signifikan, karena disiplin merupakan indikator keberhasilan utama dalam pembentukan karakter. Keberhasilan peserta didik dalam pembentukan karakter ini, sedikit banyaknya dipengaruhi oleh ketegasan dalam menerapkan metode bai'at. Dalam penelitian ini penulis menggunakan metode deskriftif kualitatif untuk mengetahui cara disiplin diajarkan, cara disiplin dilaksanakan serta faktor pendukung dan penghambat penerapan disiplin yang diajarkan dan dilaksanakan. Penulis juga menggunakan metode kuantitatif untuk mengetahui dampak pengajaran dan pelaksanaan disiplin melalui bai'at dalam pembentukan karakter peserta didik. Pelaksanaan penelitian ini dilakukan di Pesantren Persatuan Islam 1 Bandung, dan yang menjadi respondennya adalah peserta didik tingkat X Mualimien yang berjumlah 137 orang. Hasil penelitian ini menunjukkan bahwa pengajaran disiplin berada pada kategori baik, dengan rata-rata skor 3, 562 . Adapun pelaksanakan disiplin berada pada kategori baik, dengan rata-rata skor 3,562. Kemudian faktor pendukung dan penghambat pada kategori baik dengan rata-rata skor 3, 562. Sedangkan dampak pengajaran dan pelaksanaan disiplin melalui bai'at dalam pembentukan karakter peserta didik berada pada kategori sangat baik, dengan rata-rata skor 4, 242. Dengan demikian, berdasarkan hasil perhitungan diketahui bahwa disiplin melalui bai'at berdampak positif terhadap pembentukan karakter peserta didik kelas X Mualimien di Pesantren Persatuan Islam 1 Bandung.
\end{abstract}

Kata Kunci: Bai'at; disiplin; karakter.

\title{
PENDAHULUAN
}

Akhlak dapat tumbuh dan berkembang melalui proses pendidikan, khususnya pendidikan agama. Nilai-nilai yang meresap pada diri manusia melalui pendidikan tersebut akan membentuk daya tahan tersendiri untuk menghadapi godaan, ancaman dan akan membentuk tingkah laku yang sesuai dengan norma-norma agama. Akhlak dapat terbentuk dan menetap dalam diri seseorang dengan latihan atau pembiasaan yang konsisten dan disiplin. Disiplin mengarahkan terhadap tingkah laku seseorang kearah yang positif (Prayoga, 2019). Disiplin dapat menumbuhkan rasa patuh terhadap peraturan-peraturan yang berlaku di keluarga, sekolah, maupun masyarakat. Dengan disiplin akan membantu jalannya pendidikan, menyelesaikan masalah yang ada dengan baik dan jika tidak disiplin maka akan menghambat proses pendidikan. Menurut Danim 
disiplin dapat membentuk prilaku atau tingkah laku kearah yang positif serta dapat membentuk peserta didik yang relatif menjadi baik. Untuk merubah serta membiasakan prilaku anak didik agar sesuai dengan nilai-nilai Islam, metode Qur'ani lebih tepat digunakan dibanding dengan metode konvensional (Danim, 2011; Hamalik, 1995).

Berdasarkan studi pendahuluan yang dilakukan penulis pada saat melakukan pembelajaran di sekolah, dalam penyampaian materi ajar pada mata pelajaran agama Islam oleh pendidik kepada peserta didik lebih sering menggunakan metode konvensional. Dengan metode konvensional itu pendidik menjelaskan teori di depan kelas, mendemonstrasikan, memberikan tugas. Dengan metode pembelajaran tersebut, banyak peserta didik yang kurang memahami dan menghayati nilai yang terkandung di dalam materi yang diajarkan. Sehingga penyerapan nilai keagamaan sering terlupakan dan tidak tertanamkan dalam kehidupan sehari-hari. Maka dari itu dugaan penulis metode bai'at akan berperan efektik untuk memantau pembinaan kedisiplinan yang dilakukan oleh pendidik terhadap peserta didik melalui pelaksanaan pembelajaran pendidikan khususnya pendidikan Islam. Sebagaimana metode baiat ini telah dicotohkan oleh Rasulullah kepada para sahabatnya dan berperan sangat efektif untuk mengubah prilaku para sahabat menjadi lebih bertanggung jawab (Fuad, 2018).

\section{METODE}

Pendekatan yang digunakan dalam penelitian ini adalah pendekatan kualitatif dan kuantitatif yakni penelitian yang dilakukan dalam konteks alami. Penelitian ini bertujuan memahami subjek penelitiannya secara mendalam dan bersifat interpretatif, artinya mencari temuan makna. Penelitian kualitatif menggunakan dan mengandalkan data yang bersifat verbal yang rinci dan mendalam dalam beragam bentuknya (Sugiyono, 2016). Dan pendekatan kuantitatif, sebagiamana metode kuantitatif ialah data yang diperoleh dari angket yang meliputi data tentang peningkatan disiplin dalam pembentukan karakter peserta didik melalui baiat (Moleong, 2017). Sesuai dengan tujuan penelitian ini sebagaimana telah dituliskan di atas yakni untuk mengetahui pelaksanaan baiat, maka jenis penelitian yang digunakan adalah penelitian kualitatif berbentuk deskriptif. Selanjutnya menggunakan metode kuantitatif untuk mengetahui pengaruh metode baiat terhadap perubahan tingkat kedisiplinan dan akhlak peserta didik. 


\section{PEMBAHASAN}

\section{Pengajaran Disiplin di Pesantren Persatuan Islam 1 Bandung}

Pesantren Persatuan Islam 1 Bandung dalam pengajaran disiplin selalu mengaitkan dengan pendekataan nilai nilai keagamaan, seperti diadakannya pelatihan Sanlat (Peserta Didik Teladan). Didalamnya ada pengajaran tentang disiplin dalam pelaksanaan ibadah kepada Allah dan disiplin dalam menjalankan contoh Rasulullah Saw. Disiplin dalam melaksanakan perintah Allah, apabila kita tepat waktu dalam melaksanakan shalat yang 5 waktu, disiplin dalam melaksanakan shaum wajib, dan disiplin terhadap birul walidain atau hormat kepada kedua orang tua. Adapun disiplin dalam melaksanakan contoh Rasulullah S.A.W. adalah dengan selalu melaksanakan shalat sunnah, shaum sunnah, selalu mengucapkan salam kepada orang lain dan rajin bersedekah. Hal tersebut merupakan contoh pengajaran disiplin yang di ajarkan di Pesantren Persatuan Islam 1 Bandung.

Kemudian selain pengajaran disiplin terhadap pendekatan nilai nilai keagamaan, ada juga disiplin dalam pengajaran sosial kemasyarakatan dan keorganisasian selaku umat beragama. Salah satunya yaitu diadakannya LDK (Latihan Dasar Kepemimpinan) atau LMK (Latihan Manajamen Kepemimpinan). Kegiatan tersebut merupakan suatu program pengajaran yang setiap tahun diadakan, sebagai wujud realisasi peningkatan disiplin terhadap peserta didik di Pesantren Persatuan Islam 1 Bandung (Zakian, 2013). Dalam pengajaran disiplin harus dengan berbagai cara kita lakukan sebagai wujud pentingnya disiplin. Hal tersebut sejalan dengan pendapat Durkheim ada dua unsur semangat disiplin yakni: (1) Keinginan akan adanya keteraturan. Karena kewajiban dalam keadaan yang sama akan selalu sama, dan karena kondisi-kondisi pokok kehidupan banyak yang telah pasti dan berlaku setiap orang, misalnya: jenis kelamin, status pekerjaan, dan situasi sosial, maka tampaknya akan mustahil bahwa seseorang akan merasa senang bila orang tersebut bisa memenuhi kewajibannya tetapi menolak hal-hal yang sifatnya teratur dan terbiasa. (2) Semangat disiplin mengandung apa yang disebut keinginan yang tidak berlebih-lebihan dan penguasaan diri. Seorang anak tidak mempunyai perasaan bahwa kebutuhan - kebutuhannya punya hambatan yang wajar (Hamalik, 1995; Muhaimin, 1996). 
Sebagimana Wantah mengatakan bahwa disiplin sebagai kebutuhan perkembangan dan sekaligus upaya pengembangan anak untuk berperilaku sesuai dengan aturan dan norma yang ditetapkan oleh masyarakat mempunyai lima unsur penting. Kelima unsur tersebut sebagai berikut: (1) aturan sebagai pedoman tingah laku, (2) kebiasaankebiasaan, (3) hukum untuk pelanggaran aturan, (4) penghargaan untuk perilaku yang baik yang sejalan dengan peraturan yang berlaku, dan (5) konsistensi dalam menjalankan aturan baik dalam memberikan hukuman maupun dalam penghargaan (Prayoga et al., 2018; Prayoga et al., 2019).

\section{Pelaksanaan Disiplin di Pesantren Persatuan Islam 1 Bandung}

Pesantren Persatuan Islam merupakan salah satu pesantren yang modern yang memadukan ilmu keagamaan dan ilmu pengetahuan umum. Sehingga dalam pelaksanaan pembiasaan disiplin di Pesantren tersebut menggabungkan ajaran Al-Quran dan Hadits sebagai penguat landasan utama. Sebagai contoh realisasi pelaksanaan disiplin yaitu pengucapan Bai'at atau janji Peserta Didik sebagai berikut:

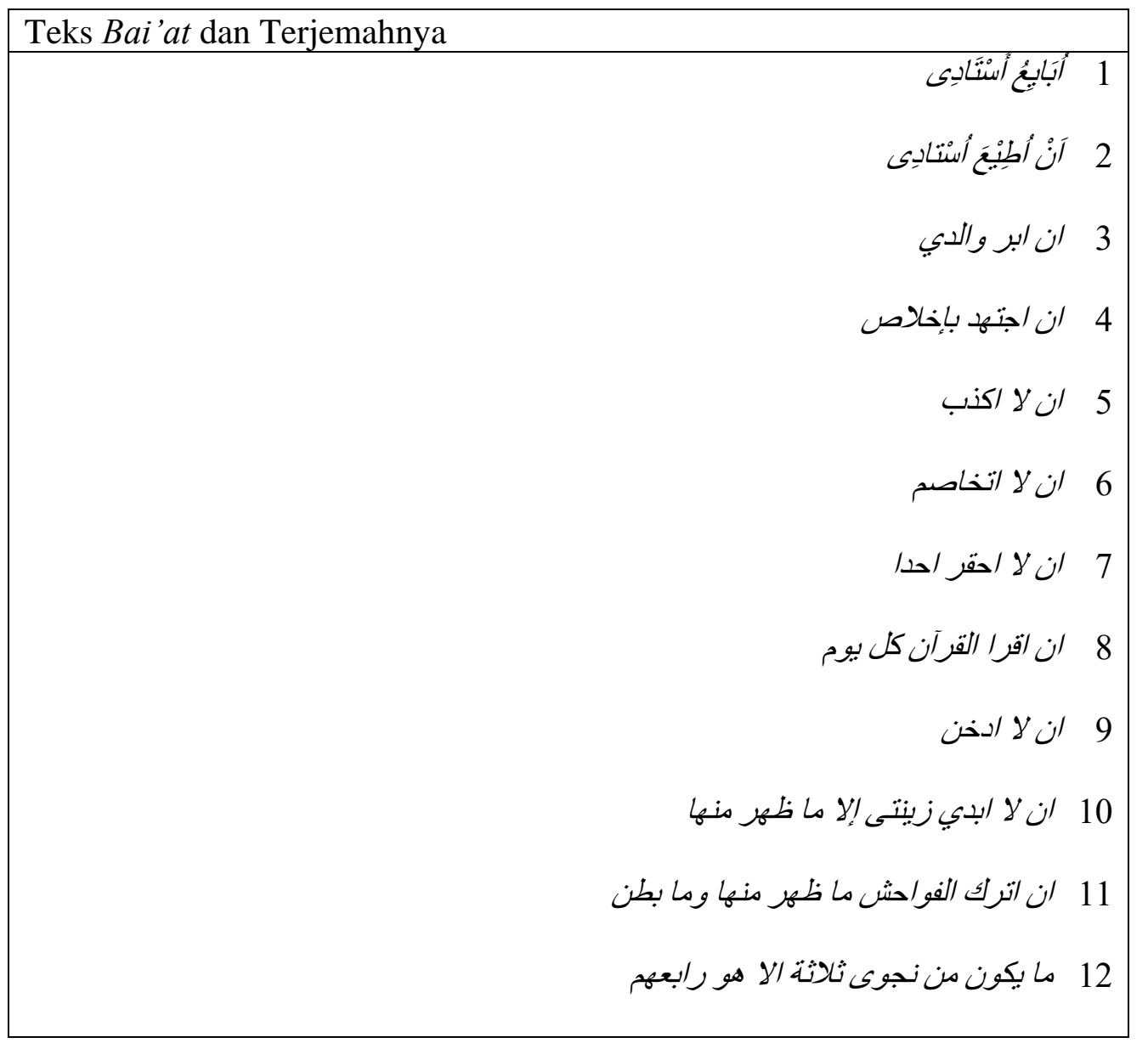




\section{3 ورل خمسة الا هو سادسهم \\ 14 ورل ادنسى من ذللك ولا اكثر ال هو معهم /بن ما كانوا}

Saya berjanji pada $u s t a d z \mathrm{ku}$.

Saya akan menaati ustadzku.

Saya akan berbuat baik pada kedua orang tuaku.

Saya akan bersungguh- sungguh dengan penuh keikhlasan.

Saya tidak akan berdusta.

Saya tidak akan bertengkar.

Saya tidak akan mencela seseorang.

Saya akan membaca Alquran setiap hari.

Saya tidak akan merokok.

Saya tidak akan menampakkan perhiasanku kecuali yang biasa tampak.

Saya akan meninggalkan kejelekan yang tampak dan yang tidak tampak.

Tiada pembicaraan rahasia antara tiga orang, melainkan Dialah (Allah) yang keempatnya.

Dan tiada pembicaraan lima orang melainkan Dialah yang keenamnya.

Dan tiada pula pembicaraan antara jumlah yang kurang dari itu atau lebih banyak melainkan Dia akan bersama mereka di mana pun mereka berada.

Tabel 1 : Teks Bai'at Peserta Didik (Pesantren Persatuan Islam, 2020)

Baiat diatas berfungsi sebagai dasar dari peraturan Pesantren yang lebih memberikan penguatan dan penyerapan ke dalam diri peserta didik dengan diikrarkan sehari sekali sebagai bagian Islamic character building yang bersifat pengikat dan pengingat bagi kehidupan keseharian peserta didik baik di lingkungan sekolah maupun di luar sekolah, baik dalam KBM maupun di luar KBM. Rangkaian peraturan tersebut bagi Pesantren merupakan optimalisasi peraturan yang sifatnya tidak hanya otoritatif, namun hendak memberikan internalisasi kesadaran dalam keseharian peserta didik secara menyeluruh (Nurdiana \& Prayoga, 2018; Sahmudin \& Prayoga, 2019).

Dengan demikian, janji peserta didik tersebut sebagai pedoman peningkatan disiplin dalam penerapan aturan-aturan yang ada di sekolah tersebut dan diketahui oleh semua peserta didik pada saat penerimaan peserta didik baru (Nurdyansyah \& Fahyuni, 2016; Wena, 2009). Semuanya itu sebagai wujud perubahan tingkah laku kearah yang lebih baik dalam kehidupan sehari-hari. Hal ini sependapat dengan (Arikunto, 2002) yang menuturkan bahwa peraturan dan tata tertib merupakan sesuatu untuk mengatur perilaku yang diharapkan terjadi pada diri Peserta Didik. Peraturan yang harus dipenuhi 
Peserta Didik di dalam kelas pada waktu pelajaran sedang berlangsung, meliputi antara lain (Musfiqon, 2012; Tu'u, 2004): (a) mendengarkan dengan baik apa yang sedang dikatakan atau diperintahkan oleh pendidik; (b) mendengarkan dengan baik apa yang dikatakan oleh teman-temannya di kelas; (c) tidak berbicara tanpa seizin pendidik; (d) memberi jawaban jika pendidik mengajukan pertanyaan; (e) tidak makan atau minum jika pendidik tidak mengijinkan; (f) tidak keluar dari kelas jika tidak ada ijin dari pendidik; (g) Melakukan hal-hal yang menyimpang dari kegiatan belajar mengajar harus seizin pendidik dan sebagainya.

\section{Faktor Pendukung dan Penghambat Penerapan Disiplin}

Faktor Pendukung Penerapan Disiplin di Pesantren Persatuan Islam (PPI) 1 Kota Bandung meliputi; pertama, sudah terbentuknya aturan atau tata tertib pesantren secara baku, sebagai bentuk daya dukung peningkatan disiplin di Pesantren Persatuan Islam 1 Bandung. Dalam ketercapaian suatu tujuan pendidikan di Pesantren tersebut, dalam hal ini tentang kedisiplinan di Pesantren Persatuan Islam 1 Bandung tidak hanya mengandalkan atau menggantungkan kepada PMA Bidang Kepeserta Didikan saja selaku tugas pokok dan fungsinya. Akan tetapi adanya kerja sama dari semua pendidik dan staf sekolah dalam peningkatan disiplin di pesantren persatuan islam 1 bandung (Fuad, 2018). Kedua, keterkaitan orang tua dalam keberhasilan pelaksanaan disiplin juga berpengaruh dalam hal kedisiplinan, setelah hasil wawancara dengan salah satu orang tua peserta didik Pesantren Persatuan Islam 1 Bandung. Mengatakan Bahwa dari mulai rumah lah penerapan disiplin dilaksanakan, dan di sekolah pun akan terbiasa disiplin (Muslim, 2018).

Faktor Penghambat Penerapan Disiplin Pesantren Persatuan Islam (PPI) 1 Kota Bandung meliputi; pertama, faktor jarak rumah dengan sekolah jauh. Berdasarkan hasil penelitian didapatkan informasi bahwa 30 persen peserta didik Pesantren Persatuan Islam 1 Bandung rumahnya jauh dengan sekolah, sekitar $2 \mathrm{KM}$ jarak tempuh pergi dari rumah ke sekolah. Kedua, faktor keluarga. Berdasarkan hasil penelitian didapatkan informasi dari konselor bimbingan konseling, terdapat beberapa peserta didik yang orang tua nya sudah tidak satu rumah lagi, diakibatkan kurang perhatian keluarga dan berdampak terhadap kedisiplinan. 


\section{Realita Peningkatan Disiplin Melalui Bai'at Peserta Didik}

Dalam penelitian ini penulis mengungkapkan peningkatan disiplin melalui bai'at peserta didik di Pesantren Persatuan Islam 1 Bandung. Selanjutnya diuraikan bahwa variabel peningkatan disiplin di Pesantren Persatuan Islam 1 Bandung, berdasarkan analisis data yang telah diolah dengan menggunakan bantuan data SPSS menggambarkan bahwa peningkatan disiplin dimensi disiplin menegakkan peraturan memperoleh nilai rata-rata cukup baik, peningkatan disiplin dimensi disiplin waktu memperoleh nilai rata-rata baik, peningkatan disiplin dimensi disiplin sikap memperoleh nilai rata-rata baik, peningkatan disiplin dimensi disiplin menumbuhkan motivasi memperoleh nilai rata-rata baik dan peningkatan disiplin dimensi disiplin beribadah memperoleh nilai rata-rata baik.

\section{Realita Pembentukan Karakter Peserta Didik}

Dalam penelitian ini penulis mengungkapkan pembentukan karakter peserta didik di Pesantren Persatuan Islam 1 Bandung. Selanjutnya diuraikan bahwa variabel pembentukan karakter peserta didik di Pesantren Persatuan Islam 1 Bandung, berdasarkan analisis data yang telah di olah dengan mengunakan bantuan data SPSS menggambarkan bahwa pembentukan karakter peserta didik dimensi jujur memperoleh nilai rata-rata baik, pembentukan karakter peserta didik dimensi disiplin memperoleh nilai rata-rata sangat baik, pembentukan karakter peserta didik dimensi percaya diri memperoleh nilai rata-rata baik, pembentukan karakter peserta didik dimensi gigih memperoleh nilai rata-rata sangat baik, pembentukan karakter peserta didik dimensi toleransi memperoleh nilai rata-rata sangat baik, pembentukan karakter peserta didik dimensi kreatif memperoleh nilai rata-rata sangat baik dan pembentukan karakter peserta didik dimensi bertanggung jawab memperoleh nilai rata-rata sangat baik (Mulyasa, 2013).

Dengan hasil penelitian ini diharapkan akan membawa manfaat serta sumbangan data yang dapat dijadikan acuan selanjutnya khsusnya bagi Pesantren Persatuan Islam 1 Bandung, lebih luasnya lagi untuk penelitian berikutnya bahwa terbukti pengajar dan pelaksanaan disiplin di Pesantren Persatuan Islam 1 Bandung mampu meningkatkan disiplin melalui bai'at dalam pembentukan karakter peserta didik. Akan tetapi perlu di tingkatkan lagi penerapan disiplin untuk memperolah hasil yang maksimal. Tentunya penelitian masih jauh dari kesempurnaan karena masih banyak faktor lainnya yang 
dapat meningkatkan kedisiplinan di Pesantren Persatuan Islam 1 Bandung selain penggunaan disiplin melalui bai'at.

\section{Dampak Pengajaran dan Pelaksanaan Disiplin dalam Pembentukan Karakter Peserta Didik}

Berdasarkan hasil perhitungan data yang dilakukan menggunakan program SPSS di dapatkan hasil sebagai berikut:

\begin{tabular}{|c|c|c|c|c|c|}
\hline \multicolumn{6}{|c|}{ Coefficients $^{\mathrm{a}}$} \\
\hline \multirow[b]{2}{*}{ Model } & \multicolumn{2}{|c|}{$\begin{array}{l}\text { Unstandardized } \\
\text { Coefficients }\end{array}$} & \multirow{2}{*}{$\begin{array}{l}\text { Standardi } \\
\text { Zed } \\
\text { coefficients } \\
\text { Beta }\end{array}$} & \multirow[b]{2}{*}{$\mathbf{T}$} & \multirow[b]{2}{*}{ Sig. } \\
\hline & B & Std. Error & & & \\
\hline $\begin{array}{l}1 \\
\text { (Constant) }\end{array}$ & $\begin{array}{l}-28764.7 \\
.691\end{array}$ & $\begin{array}{l}4229.248 \\
.063\end{array}$ & .933 & $\begin{array}{l}-6.801 \\
10.983\end{array}$ & $\begin{array}{l}.000 \\
.000\end{array}$ \\
\hline Disiplin & & & & & \\
\hline
\end{tabular}

Tabel 2: Hasil Analisis Regresi Linear (Researcher Data SPSS V.2.6, 2020)

Dependent Variabel : Pembentukan Karakter

Persamaan regresinya sebagai berikut:

$Y^{\prime}=-28764,7+0,691 X$

Angka-angka ini dapat diartikan sebagai berikut:

Konstanta sebesar -28764,7; artinya jika variabel disiplin (X) nilainya adalah 0 , maka volume Pembentukan Karakter (Y') nilainya negatif yaitu sebesar 28764,7.Koefisien regresi variabel disiplin (X) sebesar 0,691; artinya jika disiplin mengalami peningkatan Rp.1, maka pembentukan karakter (Y') akan mengalami peningkatan disiplin Rp.0,691. Koefisien bernilai positif artinya terjadi hubungan positif antara disiplin dengan pembentukan karakter, semakin meningkatnya disiplin maka semakin meningkatkan pembentukan karakter. Dalam hal ini penulis menggunakan Uji Koefisien Regresi Sederhana (Uji t), Uji ini digunakan untuk mengetahui apakah variabel independen $(\mathrm{X})$ berdampak secara signifikan terhadap variabel dependen $(\mathrm{Y})$. Signifikan berarti dampak yang terjadi dapat berlaku untuk populasi (dapat digeneralisasikan). Oleh karena nilai t hitung > t tabel $(10,983>3.151)$ maka Ho ditolak, artinya bahwa ada dampak secara signifikan antara peningkatan disiplin melalui bai'at dengan pembentukan karakter peserta didik. Jadi dalam kasus ini dapat disimpulkan bahwa disiplin melalui bai'at berdampak terhadap pembentukan karakter peserta didik di tingkat Mualimien Pesantren Persatuan Islam 1 Bandung. 


\section{KESIMPULAN}

Dari hasil penelitian mengenai peningkatan disiplin melalui bai'at dalam pembentukan karakter peserta didik di Pesantren Persatuan Islam 1 Bandung dapat disimpulkan sebagai bahwa; Pertama, pengajaran disiplin di Pesantren Persatuan Islam 1 Bandung berada pada kategori baik. Hal ini menggambarkan bahwa pada umumnya responden memberikan tanggapan baik terhadap pengajaran disiplin dilihat dari dimensi nilai rata-rata kedisiplinan. Kedua, adapun pelaksanaan disiplin di Pesantren Persatuan Islam 1 Bandung berada pada kategori baik. Hal ini menggambarkan bahwa pada umumnya responden memberikan tanggapan baik terhadap pelaksanaan disiplin dilihat dari nilai rata-rata dimensi kedisiplinan. Ketiga, faktor pendukung penerapan disiplin di Pesantren Persatuan Islam 1 Bandung berada pada kategori baik. Hal ini menggambarkan bahwa pada umumnya responden memberikan tanggapan baik terhadap faktor pendukung penerapan disiplin dilihat dari nilai rata-rata dimensi kedisiplinan. Dan faktor penghambat penerapan disiplin dilihat dari nilai rata-rata dimensi kedisiplinan ada, tidak semua dimensi kedisiplinan nilai rata-ratanya cukup baik. Keempat, dampak pengajaran disiplin terhadap peningkatan disiplin melalui bai'at dalam pembentukan karakter peserta didik berada pada kategori baik, dengan rata-rata skor 3, 562 pada dimensi peningkatan disiplin. Pada dimensi pembentukan karakter peserta didik berada pada kategori sangat baik, dengan rata-rata skor 4, 242. Hal ini menggambarkan bahwa pada umumnya responden memberikan tanggapan baik terhadap pengajaran disiplin dan pelaksanaan disiplin di Pesantren Persatuan Islam 1 Bandung. Berdasarkan hasil perhitungan diketahui bahwa disiplin melalui bai'at berdampak positif pada pembentukan karakter peserta didik.

\section{DAFTAR PUSTAKA}

Arikunto, S. (2002). Prosedur Penelitian Suatu Pendekatan Praktek. Jakarta: PT Rineka Cipta.

Danim, S. (2011). Pengembangan Profesi Guru. Kencana Prenada Media Group.

Fuad, D. H. (2018). PMA Bidang Kepeserta Didikan. D. H. Fuad, Pewawancara.

Hamalik, O. (1995). Kurikulum dan Pembebasan. Bumi Aksara.

Moleong, L. J. (2017). Metodologi Penelitian Kualitatif (Edisi Revisi). In PT. Remaja Rosda Karya. 
Muhaimin. (1996). Strategi Belajar. CV. Citra Media.

Mulyasa, E. (2013). Pengembangan dan Implementasi Kurikulum. PT. Remaja Rosdakarya.

Musfiqon. (2012). Pengembangan Media dan Sumber Pembelajaran. PT. Prestasi Pustakaraya.

Muslim, A. (2018). Hasil Wawancara Responden: Orang Tua Peserta Didik. A. Muslim, Pewawancara.

Nurdiana, M., \& Prayoga, A. (2018). Fungsi-Fungsi Manajemen dalam Kegiatan Ekstrakurikuler Pramuka di Madrasah. Madrasa: Journal of Islamic Educational Management, 1(1), 9-15. http://madrasa.id/index.php/madrasa/article/view/2/2

Nurdyansyah, \& Fahyuni, E. F. (2016). Inovasi Model Pembelajaran. In Nizmania Learning Center.

Pembelajaran, M., Quran, T., \& Prayoga, A. (2018). Manajemen pembelajaran tahfidzul quran berbasis metode yaddain di mi plus darul hufadz sumedang.

Pesantren Persatuan Islam. (2020). Teks Bai'at Peserta Didik 2019-2020. PPI Bidang Tarbiyah.

Prayoga, A. (2019). Manajemen Program Pembinaan Akhlak Karimah Peserta Didik Melalui Ekstrakurikuler. Jurnal Isema : Islamic Educational Management, 04(01), 93-104. https://doi.org/10.15575/isema.v4i1.5142

Prayoga, A., Jahari, J., \& Fauziah, M. (2019). Manajemen Program Vocational Life Skill Pondok Pesantren. J-MPI (Jurnal Manajemen Pendidikan Islam), 04(02), 97106. https://doi.org/10.18860/jmpi.v4i2.8093

Sahmudin, S., \& Prayoga, A. (2019). Meningkatkan Kompetensi Pedagogik Pendidik Dalam Pembelajaran Melalui Supervisi Akademik. Al-Mau'izhoh, 1(2). https://www.jurnal.unma.ac.id/index.php/am/article/view/1673

Sugiyono. (2016). Metode Penelitian Kuantitatif, Kualitatif, dan R\&D (24th ed.). Alfabeta.

Tu'u, T. (2004). Peran Disiplin pada Prilaku dan Prestasi Peserta Didik. Gramedia Widiasarana Indonesia.

Wena. (2009). Strategi Pembelajaran Inovatif Kontemporer: Suatu Tinjauan Konseptual Operasional. Jakarta: PT. Bumi Aksara.

Zakian, I. (2013). Pengaruh Motivasi dan Kompensasi Terhadap Kepuasan Kerja Serta Dampaknya Terhadap Kinerja Asatidzah di Mualimien PPI 2 Bandung. STIE Pasundan. 